\title{
Power Direct Trade Reform in China and the Role of the Competition Law
}

\author{
Lanfang Fei ${ }^{1, *}$ and Sen Liang ${ }^{2}$ \\ ${ }^{1}$ Associate Professor, Faculty of law, Jinan University, Guangzhou, China \\ ${ }^{2}$ Phd student, Faculty of law, Jinan University, Guangzhou, China \\ *Corresponding author. Email: fei27@hotmail.com
}

\begin{abstract}
China is in a new round of reform and is pushing ahead with freeing its power sector to cut prices and boost efficiency. In the face of the new round of reforms, the Development and Reform Commission of China delivered the first anti-monopoly decision on a monopoly agreement entered into by electricity suppliers. This paper discusses the first anti-monopoly case in the electricity sector in China, examining the arguments raised by the anti-monopoly enforcement authority and the authority's subsequent actions. We also reveal the obstacles to competition raised by electricity reform and the inadequacies of the competition authority in dealing with these anti-competitive problems.
\end{abstract}

Keywords: Anti-monopoly law, Power sector, Price reform, Direct power purchase, Government.

\section{INTRODUCTION}

The In August of 2017, the Shanxi province branch of the National Development and Reform Commission (NDRC) of China imposed anti-monopoly penalties totaling RMB 73.88 million on the Shanxi Electric Power Industry Association ("Association") and 23 power companies for entering into and implementing monopolistic power direct transaction agreements. The NDRC's investigation revealed that in 2016, the Association had arranged for 23 power companies to reach and implement agreements on fixing the price of power direct transactions for large customers, which violated the Anti-Monopoly Law (AML) (Yanbei, 2008). The NDRC held that the Association was the major planner and organizer of the horizontal pricefixing agreements and thus fined it the maximum amount of 500,000 RMB. The 23 companies that had participated in making and implementing the agreements were also found to have violated the AML and fined RMB 72.88 million.

This was the first monopoly case in the Chinese power industry. The case originated from a situation created by a new kind of electricity transaction mechanism called large customer direct-powerpurchasing ("DPP"), under which the qualified customers could purchase electricity directly from the generation companies by paying reasonable electricity transmission and distribution fees to the power network enterprises (Tang, 2016). As an important part of the electricity market-oriented reform (Xu, 2005), the DPP mechanism is aimed at improving the price formation mechanism and enhancing the level of the optimal allocation of power resources. However, using the DPP as a way to improve the price formation mechanism seemed to create new misrepresentations of competition. How did this happen? What are the main obstacles to competition and market efficiency that have been raised by the Chinese power reform, especially by the DPP mechanism? Furthermore, to what extent can China's competition policy help reduce the anti-competitive obstacles in the power industry?

This paper will try to address the above issues through an in-depth analysis of the first anti-monopoly case. Part I will sort out the details of the case and will introduce the background of the investigation process, the hearing procedures and the administrative decision made by the NDRC. Part 2 then explores the in-depth administrative reasons underlying the case, by addressing the implementation history of large consumer DPP reform in the Shanxi Province and the administrative factors causing monopolistic behaviour. Part III discusses the implications of the case, followed by an analysis of the problems in enforcing antimonopoly law against a background of changeable and complex electricity reform in China. 


\section{THE FLOW OF THE DDP REFORM}

By the end of 2016, among the 31 provinces in China, there were twenty-four provinces that had adopted the pilot project of DPP between large customers and power generation enterprises, at different degrees, including the provinces of Chongqing, Heilongjiang, Liaoning, Jilin, Henan, Hubei, Hunan, Shandong, Shanxi, Anhui, Jiangsu, Fujian, Guangdong, Sichuan and Yunnan, Jiangxi, Ningxia, Guangxi, Shaanxi, Zhejiang, Guizhou, Gansu, Inner Mongolia and Xinjiang. Nearly all pilot provinces had released normative documents setting out trading rules.

In examining the pilot programmes and trading rules of the provinces, some common features in these rules, which may raise anti-competitive concerns, have been found.The first problem is the control of market entrance by the local government. In almost all of the provinces in which DPP has been implemented, the local governmental authorities have set up entry thresholds for both parties, and the market subjects involved in direct trading are very limited. The provinces always define the scope of the qualified large customers by adopting the basic metropolitan rules, such as "having legal personality, accounting for financial independence, good credit, being able to bear civil liabilities on their own" and "hard power consumption and high electricity rating". In addition, there are special qualifying provisions, such as being "in line with the industrial policy", "meeting the requirements of energy conservation and environmental protection", "no power plant owned by ourselves," and "advanced energy consumption targets". Generally, in the implementation of large user direct trading reform, provinces and cities in the actual operation of direct transactions have given priority to the protection of the dominant enterprises and the high-tech enterprises in the provinces and cities, with a view of promoting industry integration and development through differential electricity prices to optimize their industrial structure. Power generation enterprises that participate in the DPP also must meet the requirements of national energy savings and emission reduction, local industrial policies and other requirements. On the other hand, the specific transaction methods and processes in different provinces vary. A majority of the provinces have adopted bilateral negotiation transactions; some provinces have adopted centralized matching transactions and other modes, while a few provinces have tried using online bidding transactions, listing transactions and other modes.

Moreover, the local governments have interfered with the price formation of DDP. Theoretically, the direct transaction price should be negotiated between the user and the power generation company. However, in reality, the transaction price is not entirely formed by the market. First, according to the pilot pricing mechanisms implemented in the majority of the provinces, the DPP price usually consists of the direct transaction price, the transmission and distribution price of the power grid, the transmission and distribution losses, the ancillary services fee, and the government funds and surcharges. The government would be involved in determining the last three components of the total price. As there is no unified requirement for the transmission and distribution prices, the local government would also interfere with the coordination of that component of the price. For transmission and distribution losses, some provinces and cities include losses in their transmission and distribution tariffs, while others may have separate ways to cover these losses. In terms of ancillary services, some pilots have difficulty in quantifying and accounting for ancillary services. At present, there is no uniform pricing mechanism for ancillary services.

The subsidy problem is even more complicated. Due to the "electricity price concessions" of direct trading, by using direct trade pricing, local governments may wish to reduce the electricity prices of local pillar industries to stimulate the development of local high energy-consuming industries and to provide incentives for attracting investment to ensure local employment and taxation. In addition, large power users are mainly industrial users, and they are the receivers of government industrial subsidies for agricultural policies. They objectively bear a considerable amount of crosssubsidy from the government. After large-user direct transactions are carried out, major power users that have participated in direct transactions purchase power directly from the power generation companies. In principle, they are no longer responsible for paying the "cross-subsidy" part of the electricity prices, which are covered by the cross-subsidization in the form of government funds. The cost of electricity for large users that participate in direct transactions and that directly compete with other large users in the same industry will be significantly lower than that of enterprises that do not participate in direct transactions in the same industry.

Finally, there is no unified trading platform for DDP. The trading platform guarantees the direct, standardized, fair and open trading of power for large users. The platform was intended to consolidate and report related transaction information for power generation companies, large power users, and power grid companies, providing a platform for negotiation and bidding. At present, some of China's direct transaction pilot regions have adopted direct-negotiated trading models for power generation companies and large users, but no special trading platform has been established to directly handle large users. Work issues and a lack of standardized management have also presented challenges. In addition, although some pilots have established a relevant trading platform, due to special interests, companies have not participated in the 
actual direct transaction process, as seen in the case of the pilot of the East China Power Grid.

\section{THE IMPACT OF THE FLOW ON COMPETITION}

There are mainly two types of competitive issues that arise in the direct-supply reform of large-scale users. The first type are the issues related to the formation of the cartel that emerged in the direct-supply market for large-scale users, especially the cartel that engaged in price collusion; the other type of competitive issues are the actions taken by local governments in exercising an administrative monopoly through regulation of market access, price composition and subsidies in designing a DPP plan for the sake of local protection. This second type of local administrative interference, in actuality, virtually induced the formation of the first-level cartel.,

In general, the Chinese anti-monopoly law enforcement agency's handling of the Shanxi Electric Power Case was a response to the first level problem, even though it should be noted that this response is incomplete from the viewpoint of the law enforcement process and the enforcement decision. There were many imperfections in the anti-monopoly agency's enforcement decisions and procedures, First, regarding the text of the law enforcement decision, the decision was simple and the full text was only a few hundred words. The decision of this case was ultimately made by the Shanxi Development and Reform Commission under the instruction of the NDRC. The transparency of the law enforcement procedures was lacking. The final decision has not been officially announced on the website of the NDRC. In terms of the substance of the decision, the anti-monopoly agency did not give full consideration and analysis to the defences of the enterprises accused of monopolistic behaviour. In the context of the Chinese AML law, all horizontal and vertical agreements prohibited under Articles 13 and 14 may be exempted under Article 15 if they satisfy certain exemptions, which include the following: improving operational efficiency; enhancing the competitiveness of small- and medium-size enterprises; promoting the serving of various public interests, such as conserving energy, protecting the environment, and providing disaster relief; mitigating severe decreases in sales or inventory during economic recessions; and protecting "the legitimate interests of international trade and foreign economic cooperation." During the investigation and the hearing of the case, the enterprises that were the object of the law enforcement actions have put forward a defence consisting of a series of reasons, such as one indicating that the price collusion was a self-rescue behaviour caused by the overproduction of electricity industry. The antitrust authority did not give a full and complete response to the parties' defences. In the final decision, the law enforcement agencies did not even mention the parties' defences at all.

The reason the anti-monopoly law enforcement agency did not investigate the administrative intervention underlying the formation of this cartel is due to multiple reasons. First, it is hard to define an administrative interference arrangement as an illegal administrative monopoly. However, chapter five of the Chinese AML prohibits an "administrative monopoly,", i.e., the situation in which public and administrative government entities abuse their powers to hinder the workings of free markets. Moreover, it is difficult to define the nature of administrative behavior in power system reform. As we stated above, China's power system reform, similar to reform in other areas, followed a test-driving or so-called trial-and-error principle (Gao, 2010). The restriction of the market volume, participants, and market implementation of DPP was authorized by the central government, as the Chinese government did not want China to experience a situation similar to the "California power crisis" (Ahmad Faruqui, 2001). In other words, it "was a stateauthorized restraint on competition rather than a private restraint" (Wara, 2016). Excessive antitrust investigations may be considered as an impediment to local government reform. Moreover, it may have been hard to obtain evidence of administrative interference in price collusion. The form of the administrative intervention may have been an internal document, or even an oral instruction by the local leader.

The failure to respond to the administrative monopoly behind the cartel case reveals the dilemma of power reform itself and of the enforcement of antimonopoly law in the power industry under conflicted policy circumstances (Ma, 2008). The central government and local governments have differences in the direction and goals of power reform. This has resulted in China's electricity sector growing more and more decentralized with provincial governments increasingly in control of generation assets and provincial grids since 1980s. China's national regulatory system is mismatched with the electricity sector's provincial character. A national-provincial incongruity has created frequent conflict between the central government and provincial governments and acts as an obstacle to the implementation of national policies (Tasai, 2011). For example, when the central government is doing top-level design, it hopes to implement DPP to gradually realize the marketization of power trading. However, local governments will consider the goal of supporting local industries and promoting local economic development when implementing reform programmes. From the perspective of anti-monopoly law, that conflict also causes some new local-level administrative monopoly activity in opposition to the central-level administrative monopoly policy. The lack of an anti-monopoly law 
response to the administrative intervention of the Shanxi Provincial Government in directing the implementation of direct power supply to large users has left a hidden danger for the occurrence of similar cases in the future.

\section{CONCLUSION}

For the last 30 years, China's electricity sector has had one foot in its planned economic past and one foot in transition towards workable competition. Moving out of the planned economy and setting up an independent regulatory system is a crucial step for China's electricity sector. The future of the reform is partly determined by the extent to which direct purchase contracts can attract large industrial and commercial consumers entering the market and can help set a market-based electricity pricing mechanism (Richard J. Pierce, 1996). However, the first Anti-Monopoly case in the electricity sector revealed that the changeable electricity sector was still troubled by entrenched monopolies, tension between different levels of government and a lack of regulatory oversight and transparency. The first case showed the competition authorities' attention to electricity monopoly issues and their intention to use antitrust as a tool to prevent problems in the implementation of electricity pricing reform. Although confined by institutional imperfections, the competition agencies have only a limited space in which to operate against local government. The pursuit of the anti-monopoly case is a good start for more enforcement activity of the AML in the electricity sector to facilitate the success of the electricity market-oriented reform.

\section{ACKNOWLEDGMENTS}

This research has been supported by the National Natural Science Foundation of China (No. 71603099)

\section{REFERENCES}

[1] E Ahmad. C., Analyzing California's Power Crisis. The Energy Journal, (2001) 29-52.

[2] Gao, C. L., Evolution of China's power dispatch principle and the new energy saving power dispatch policy. Energy Policy, (2010) 7346-7357.

[3] Ma, C. H. From state monopoly to renewable portfolio: Restructuring China's electric utility. Energy Policy, (2008) 1697-1711.

[4] Q Tang, Z. L. Decision - making of Direct Customers Based on Available Transfer Capability. Power System Technology, (2016) 199-200.

[5] Richard J. Pierce, J. ANTITRUST POLICY IN THE NEW ELECTRICITY. ENERGY LAW JOURNAL, (1996) 29-58.

[6] Schneider, J. S. (. Administrative Monopoly and China's New Anti-Monopoly Law. Washington University Law Review, 2010)869.

[7] Schneider, J. S. (. Administrative Monopoly and China's New Anti-Monopoly Law. Washington University Law Review, 2010)869.

[8] Tasai, C.-m. (2011). The Reform Paradox and Regulatory Dilemma in China's Electricity Industry. Asian Survey, 520-539.

[9] Wara, M. W... Competition at the Grid Edge: Innovation and Antitrust Law in the Electricity Sector. Working Paper Series, Paper (2016) No. 491, 1-53.

[10] Xu, S. The reform of electricity power sector in the PR of China. Energy Policy, (2005) 2456-2457.

[11] Yanbei, S. K. Against Antitrust Functionalism: Reconsidering China's Antimonopoly Law. VA. J. INT'L L., (2008), 379, 383. 